\title{
Is repeated cypermethrin fumigation dangerous for the mitochondrial DNA in dry insect samples?
}

\author{
Dominik VONDRÁČEK ${ }^{1,2)}$, Michal TKOČ ${ }^{1)} \&$ Martin FIKÁČEK ${ }^{1)}$ \\ ${ }^{1)}$ Department of Entomology, National Museum, Cirkusová 1740, CZ-193 00 Praha 9, Czech Republic \\ ${ }^{2)}$ Corresponding author: dominik.vondracek@gmail.com
}

Accepted: $26^{\text {th }}$ November 2018

Published online: $14^{\text {th }}$ December 2018

\begin{abstract}
Entomological collections are the target of various insect pests, e.g. carpet beetles (Dermestidae) and booklice (Psocoptera) which can damage and completely destroy dry specimens in a relatively short time. Collections in the National Museum, Czech Republic (NMP) including the entomological ones are protected by fumigation using commercially available smoke shells 'Cytrol Super SG'; fumigation is performed twice a year. The active insecticidal substance of these smoke shells is cypermethrin (6.25\%). We tested whether the repeated cypermethrin fumigation of the NMP entomological collections negatively affects the quality of mitochondrial DNA in dry specimens and prevents the subsequent use of these samples for molecular analyses required for identification, taxonomy, systematics, and phylogenetic studies. We used 32 freshly fixed specimens of the flower chafer Oxythyrea funesta (Poda von Neuhaus, 1761) and 32 freshly fixed specimens of the brown-tailed cockroach Supella longipalpa (Fabricius, 1798). One half of specimens of both species was stored outside NMP and not fumigated (negative control), and the other half was deposited in collection hall with the NMP insect collection and directly exposed to the fumigation. Subsequently, all specimens were processed in a molecular laboratory under a standardized protocol using one leg as the source tissue after each fumigation, and the $658 \mathrm{bp}$ long barcoding region of the cytochrome oxidase I $(\operatorname{cox} 1)$ as the testing gene fragment. Results of the PCR product electrophoresis and the sequences acquired confirmed that the repeated fumigation had no negative effect on tested samples.
\end{abstract}

Key words. Entomological collections, pest protection, fumigation, cypermethrin, molecular analysis, DNA quality, cytochrome oxidase I

\section{Introduction}

Small private collections or the huge museum ones, which can store millions of specimens, are in permanent danger because of various insect pests that can destroy the dry material within a very short time after infestation. Most frequently, insect collections are infested by carpet beetles (Coleoptera: Dermestidae: Anthrenus Schaeffer, 1766 and Attagenus Latreille, 1802) or booklice (Psocoptera: Liposcelis Motschulsky, 1852), all of which are able to feed on dry insect specimens as well as on the paper of the locality and identification labels (NoTTON 2018). All entomological collections should be hence protected against insect pests, no matter how big they are.
Entomological collections of the National Museum in Prague (NMP) store more than 8 million of dried insects including thousands of primary type specimens (e.g. MacháčKová et al. 2017, KMENT \& RÉDEi 2018), historical specimens documenting insect faunas in areas that have been already destroyed, or voucher specimens documenting the distribution of insect species over time. They hence represent a valuable source of information for the society (Suarez \& Tsutsui 2004, Colvin 2014) and can be used for morphology-based as well as DNA-based research. DNA can be preserved in dry specimens for years and decades (e.g. GiLbert et al. 2007, WatTs et al. 2007, ANDERSEN \& Mills 2012). Fragments of DNA obtained 
from dry material can be used for further molecular studies such as discovering new species or studying more complex questions concerning taxonomy, systematics, population genetics, and phylogenetic studies (e.g. HeBERT et al. 2004, Burns et al. 2008, Janzen \& Hallwachs 2016).

Dry specimens can be protected by several different methods: (1) they can be frozen for a short time period in order to kill the pests and their eggs (FLORIAN 1990, BERzOLLA et al. 2011); (2) they can be permanently protected by using chemicals placed directly in boxes and cabinets in small vials where they can vaporize for a long period (PinNiger \& HARMON 1999); (3) the infestation by the pests can be prevented by repeated use of chemicals in form of smoke shells which can fumigate whole rooms. Each of these methods has some disadvantages. Freezing period should be longer than one week if the temperature is around $-20^{\circ} \mathrm{C}$, which is a standard minimum in classical freezers. These specimens are not available for study during this time and in bigger collections, a lot of freezer space capacity is required especially when a high amount of specimens is obtained (e.g. donation of a large private collection), and finally, this solution is quite power consuming. Putting chemicals directly in the boxes can be very efficient, but is also very time-consuming, especially in bigger collections (it requires regular renewing of chemicals in all boxes), and permanently exposes researchers and collection curators to the protective chemicals, which can pose health risks (Pinniger \& Harmon 1999). Repeated fumigation using smoke shells can be more suitable in larger collections, as it is fast and does not expose the collections and researchers permanently to the chemicals. Fumigation itself is quite a fast and easy process taking several hours for a large collection, and the only problem can be that it has to be done by a specialized external company. Rooms have to be closed for 2-3 days after the fumigation and later they can be visited again. Another option is to use high temperature pest eradication system (Thermo Lignum Chambers $\left.^{\circledR}\right)$. Specimens are heated in a special chamber using no chemicals at all (ACKERY et al. 2004). Unfortunately, this method is quite expensive as well as space and power consuming. Usually it is used by historical museums to protect wooden and fabric objects. See the book chapter by Pinniger \& Harmon (1999) or review by Querner (2015) for additional information about methods used to protect the collections against pests.

Very little is known about the influence of various protection methods on the quality of the DNA of the dry insect samples. Repeated freezing and defrosting has a negative effect on the DNA quality of the samples as it facilitates DNA fragmentation (SHAO et al. 2012). The empirical experience also indicates that many chemicals (e.g., ethyl acetate, benzene) largely degrade the DNA and make subsequent DNA amplification using PCR very difficult or completely impossible. The effect of the chemicals used for pest protection on the DNA quality of the samples remains nearly unknown and a small review is given in the discussion.

The collections of the National Museum (Czech Republic) are protected by regular fumigation using commercially<smiles>CC1(C)[C@H](C=C(Cl)Cl)[C@H]1C(=O)O[C@H](C#N)c1cccc(Oc2ccccc2)c1</smiles>

Fig 1. Chemical structure of cypermethrin $\left(\mathrm{C}_{22} \mathrm{H}_{19} \mathrm{Cl}_{2} \mathrm{NO}_{3}\right)$ which is the active insecticidal substance $(6.25 \%)$ in commercial available smoke shells "Cytrol Super SG” (PelGar s.r.o./Agrochema družstvo Studenec, Czech Republic).
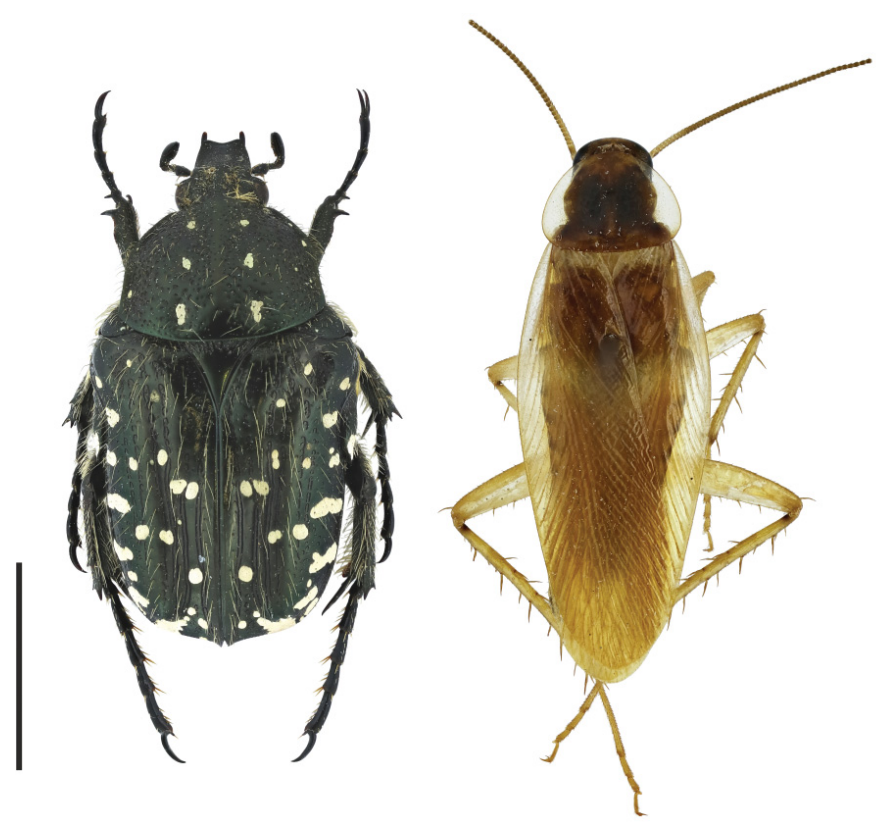

Fig 2. Habitus of organisms used in this study. Left - Oxythyrea funesta (Poda von Neuhaus, 1761), right - Supella longipalpa (Fabricius, 1798). Scale bar $=5 \mathrm{~mm}$.

available smoke shells “Cytrol Super SG” (PelGar s.r.o./ Agrochema družstvo Studenec, Czech Republic), which is done twice a year (usually in April and November). The active insecticidal substance of the smoke shell is $6.25 \%$ cypermethrin $\mathrm{C}_{22} \mathrm{H}_{19} \mathrm{Cl}_{2} \mathrm{NO}_{3}$ (Fig. 1) with synergic ingredient $2 \%$ piperonyl butoxide $\left(\mathrm{C}_{19} \mathrm{H}_{30} \mathrm{O}_{5}\right)$, which increase the effectiveness of the main active substance. Cypermethrin is a synthetic pyrethroid that works as a contact neurotoxin for insects, whereas it is declared as harmless for people and most other mammals, or birds (GAMMON et al. 1981, Lawrence \& Casida 1982, Pascual \& Peris 1992 , CANTAlamessa 1993). For more information see this file: http://npic.orst.edu/factsheets/cypermethrin.pdf. The goal of this methodological study is to find out if cypermethrin can negatively affect the quality of mitochondrial DNA (mtDNA) of the barcoding region in dry specimens, which were fumigated, and cause problems with PCR amplifications and subsequent Sanger sequencing. We focused our study on the mtDNA barcoding region of cytochrome oxidase I as it is the most widely used marker for taxonomic studies and initial screening of genetic variability before more complex molecular analyses are started. 
Table 1. Additional details about material used in this study.

\begin{tabular}{|c|c|c|c|c|c|c|c|c|c|}
\hline Taxon & Collecting & Killing & ation & $\begin{array}{l}\text { First } \\
\text { fumigation }\end{array}$ & $\begin{array}{l}\text { First } \\
\text { extraction }\end{array}$ & $\begin{array}{l}\text { PCR and } \\
\text { sequencing }\end{array}$ & $\begin{array}{l}\text { Second } \\
\text { fumigation }\end{array}$ & $\begin{array}{l}\text { Second } \\
\text { extraction }\end{array}$ & $\begin{array}{l}\text { PCR and } \\
\text { sequencing }\end{array}$ \\
\hline Oxythyrea & 9.iv.2017 & 10.iv.2017 & 11.iv.2017 & 28.iv.2017 & 3.v. 2017 & 10.-12.v.2017 & 16.xi.2017 & 23.xi.2017 & 28.-30.xi.2017 \\
\hline Supella & 19.iv.2017 & 20.iv.2017 & 21.iv.2017 & 28.iv.2017 & 3.v.2017 & 10.-12.v.2017 & 16.xi.2017 & 23.xi.2017 & 28.-30.xi.2017 \\
\hline
\end{tabular}

Table 2. Museum IDs of all samples used in this study.

\begin{tabular}{lll}
\hline Taxon & First fumigation (run I) & Second fumigation (run II) \\
\hline \multirow{3}{*}{ Oxythyrea } & NMPC-GAS-0001 to NMPC-GAS-0004 (fumigated) & NMPC-GAS-0001.1 to NMPC-GAS-0004.1 (fumigated) \\
& NMPC-GAS-0009 to NMPC-GAS-0020 (fumigated) & NMPC-GAS-0009.1 to NMPC-GAS-0020.1 (fumigated) \\
& NMPC-GAS-0033 to NMPC-GAS-0048 (negative control) & NMPC-GAS-0033.1 to NMPC-GAS-0048.1 (negative control) \\
\hline \multirow{3}{*}{ Supella } & NMPC-GAS-0005 to NMPC-GAS-0008 (fumigated) & NMPC-GAS-0005.1 to NMPC-GAS-0008.1 (fumigated) \\
& NMPC-GAS-0021 to NMPC-GAS-0032 (fumigated) & NMPC-GAS-0021.1 to NMPC-GAS-0032.1 (fumigated) \\
& NMPC-GAS-0049 to NMPC-GAS-0064 (negative control) & NMPC-GAS-0049.1 to NMPC-GAS-0064.1 (negative control) \\
\hline
\end{tabular}

\section{Material and methods}

In late March 2017, 32 fresh specimens of the flower chafer Oxythyrea funesta (Poda, 1761) were collected in Praha-Radotín (Czech Republic) and 32 fresh specimens of the brown-tailed cockroach Supella longipalpa (Fabricius, 1798) were gathered from breeding located in Czech Republic as well (Fig. 2). These two species were chosen to represent highly sclerotized $(O$. funesta $)$ and less sclerotized insects (S. longipalpa) of comparable body size $(1-1.5 \mathrm{~cm})$.

All specimens were killed by exposure to $-20^{\circ} \mathrm{C}$ in a freezer overnight, without any other chemicals involved, to assure that the DNA quality is not affected. Specimens were pinned the next day and dried up for a week at room temperature at low humidity. Once dried, they were stored in the usual black $23 \times 30 \mathrm{~cm}$ insect boxes used in the NMP. Freshly fixed specimens were used to have a direct control over the history of the samples (their age, no chemicals used during storage etc.) and to guarantee that their DNA is preserved in high quality. The material was split in two equal halves: 16 flower chafers and 16 cockroaches were stored in one box inside the NMP collection hall for testing of the fumigation effects on them (boxes were kept closed for most of the time, but open during the fumigation). The collection hall is about $22.5 \times 22.5 \times 3.15 \mathrm{~m}$ large and two smoke shells (120 g with cypermethrin concentration $6.25 \%$ per smoke shell) are used during one fumigation process; 16 flower chafers and 16 cockroaches were stored in the second box in a different building outside NMP as a negative control and were not exposed to cypermethrin or any other chemicals.

The specimens were fumigated twice (in April and November 2017) and the DNA was extracted from all of them shortly after each fumigation, both times using a single leg as a tissue source (i.e., all samples were used twice in the lab procedure). DNA was extracted using the Genomic DNA Mini Kit (Tissue) (Geneaid Biotech Ltd., Taiwan), following the standard protocols with these modifications: incubation with GT buffer was prolonged to 3 hours, incubation with GBT buffer was prolonged to 1 hour and the elution was made using 80 microliters of elution buffer. These modifications are normally used during other DNA extractions in our department for our samples to be sure that the tissue will dissolve completely and the final DNA concentration (using fresh material) after the elution step is usable for PCR reactions. Polymerase chain reaction was done with PCR Master Mix (Top-Bio, s.r.o., Czech Republic) using the standard protocol and primers (Folmer et al. 1994) to obtain the full length of the barcode region (658 bp) of cytochrome oxidase I (cox 1): LCO1490 (forward): 5'-GGTCAACAAATCATAAAGATATTGG-3'; HCO2198 (reverse): 5'-TAAACTTCAGGGTGACCAAAAAATCA-3'. The PCR program included initialization at $94^{\circ} \mathrm{C}$ for $3 \mathrm{~min}$, followed by 35 cycles of denaturation at $94^{\circ} \mathrm{C}$ for $1 \mathrm{~min}$, annealing at $50^{\circ} \mathrm{C}$ for $1 \mathrm{~min}$ and elongation at $72^{\circ} \mathrm{C}$ for 1.5 min, and final elongation at $72^{\circ} \mathrm{C}$ for 7 minutes. Negative and positive control was done for each PCR. No DNA was used for the negative control sample and a freshly killed flower chafer in ethanol from the same collecting event as samples used in this study was used as a positive control. This sample was stored in ethanol and freezer and was never fumigated. PCR products were checked on $1 \%$ agarose gel under UV light using horizontal electrophoresis and depicted with documentation system (MiniBIS Pro + GelCapture software). Purification was done using the ethanol precipitation method and the Sanger sequencing was done using the commercial service of the Macrogen Europe (the Netherlands); in all cases in both (forward and reverse) directions. Bidirectional sequences were aligned to form contigs and edited using Geneious 9.1 (KEARSE et al. 2007, http://www.geneious.com). Sequences from both runs were submitted to Zenodo scientific archive

Table 3. Requirements for Medium and High quality Bin profile as used in Geneious software.

\begin{tabular}{llll}
\hline Medium quality bin stats & \multicolumn{3}{l}{ High quality bin stats } \\
\hline Max \# disagreements & 10 & Max \# disagreements & 5 \\
\hline Min mean coverage & 1 & Min mean coverage & 1 \\
\hline Min length (approx.) & 300 & Min length (approx.) & 500 \\
\hline Min \% of reference length & 50 & Min \% of reference length & 50 \\
\hline Min \% high quality bases & 75 & Min \% high quality bases & 75 \\
\hline Min \% low quality bases & 10 & Min \% low quality bases & 10 \\
\hline Max \# ambiguities & 10 & Max \# ambiguities & 5 \\
\hline Max \# stop codons & 3 & Max \# stop codons & 0 \\
\hline
\end{tabular}


under doi 10.5281/zenodo.1484164, including original trace files from sequencing machine used in Macrogen (see Table 1 and 2 with additional details about vouchers and lab procedures).

Quality of the obtained sequences was checked using Bin profile indicator in Geneious software. The confidence/ quality for bases was set as follows: Low $<25<$ Medium $<40<$ High. Requirements for assembly binning options in Medium and High quality are summarized in Table 3.

\section{Results}

We were able to amplify all 64 samples after the first fumigation (run I) and 63 samples after the second fumigation (run II) (Fig. 3). In run I, one sample provided a rather weak band on the gel (NMPC-GAS-0012=Oxythyrea fumigated sample). In run II, sample NMPC-GAS-0024.1 (Supella fumigated sample) was not amplified and four samples had weaker band (NMPC-GAS-0001.1 = Oxythyrea fumigated sample, NMPC-GAS-0040.1 = Oxythyrea negative control, NMPC-GAS-0051.1 and NMPC-GAS-0058.1 = both Supella negative control). In both runs, positive and negative PCR controls correctly resulted in positive and negative signal, respectively. All samples including those producing weak electrophoresis bands were subsequently purified and sequenced.

Sequences were successfully obtained from all 64 (run I) and 63 (run II) amplified PCR products in both directions. Only reverse sequence for NMPC-GAS-0013 (Oxythyrea fumigated sample) had a very low quality and was not used further. All contigs of barcode from edited sequences were placed in high bin according to Geneious software. We were able to acquire a full barcode $(658 \mathrm{bp})$ for 60 samples in run I and 61 samples in run II. Samples without a full barcode from run I were: NMPC-GAS-0013 (Oxythyrea fumigated sample, 558 bp), NMPC-GAS-0015 (Oxythyrea fumigated sample, $657 \mathrm{bp}$ ), NMPC-GAS-0041 (Oxythyrea negative control, $657 \mathrm{bp}$ ), and NMPCGAS-0042 (Oxythyrea negative control, 657 bp). For run II: NMPC-GAS-0060.1 (Supella negative control, 617 bp) and NMPC-GAS-0062.1 (Supella negative control, 649

Table 4. N1 = number of successfully amplified PCR products during electrophoresis + samples with weaker band. N2 = number of successfully obtained sequences with full barcode $(658 \mathrm{bp})+$ shorter sequences. HQ\% $=$ range of percentage values in specified sets of sequences, where $\mathrm{HQ} \%$ value is the percentage of untrimmed bases in a consensus of a contig that are of high quality.

\begin{tabular}{lccc}
\hline Run I & N1 & N2 & HQ\% \\
\hline Oxythyrea fumigated samples & $15+1$ & $14+2$ & $93.2-100 \%$ \\
\hline Oxythyrea negative control & 16 & $14+2$ & $93.3-100 \%$ \\
\hline Supella fumigated samples & 16 & 16 & $94.7-100 \%$ \\
\hline Supella negative control & 16 & 16 & $96.5-100 \%$ \\
\hline Run II & $\mathbf{N 1}$ & $\mathbf{N 2}$ & HQ\% \\
\hline Oxythyrea fumigated samples & $15+1$ & 16 & $94.4-100 \%$ \\
\hline Oxythyrea negative control & $15+1$ & 16 & $97.1-100 \%$ \\
\hline Supella fumigated samples & 15 & 15 & $96.0-100 \%$ \\
\hline Supella negative control & $14+2$ & $14+2$ & $96.0-100 \%$ \\
\hline
\end{tabular}

bp). More details about percentage of high quality bases are summarized in Table 4.

Two samples whose PCR amplification (NMPCGAS-0024.1, Supella fumigated sample) and sequencing (reverse sequence of NMPC-GAS-0013, Oxythyrea fumigated sample) were not successful were re-amplified and re-sequenced using the same DNA extract, and provided high quality sequences in both cases. This indicates that the original failures of PCR amplification and sequencing were caused after the DNA extraction, and were not results of the effect of cypermethrin on the DNA quality of the respective specimens.

\section{Discussion}

Our results based on two subsequent fumigations of NMP collections applied in 2017 indicate that cypermethrin does not affect the quality of mtDNA barcoding region in dry insect samples in a way detectable using standard PCR and Sanger sequencing methods. Moreover, there is no evidence that cypermethrin affects less sclerotized samples (Supella) more than those with thicker cuticle (Oxythyrea). After two exposures of the dry specimens to cypermethrin in concentrations used for fumigation of

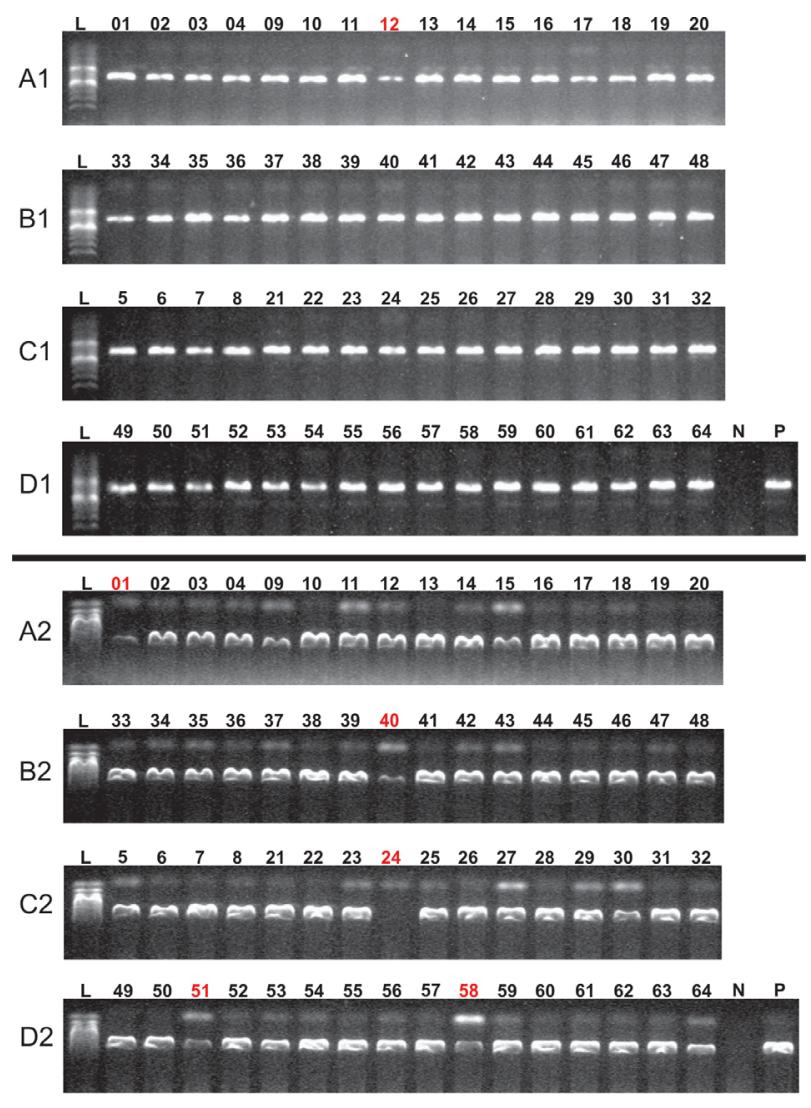

Fig 3. Quality of PCR products of all 128 samples used in this study (barcoding region of the cytochrome oxidase I) checked on the $1 \%$ agarose gel in the horizontal electrophoresis. A1-D1 - run I. A1 - Oxythyrea funesta (fumigated samples), B1 - O. funesta (negative control), C1 - Supella longipalpa (fumigated samples), D1 - S. longipalpa (negative control). A2-D2 - run II (same legend as in run I). $\mathrm{L}=$ DNA ladder, $\mathrm{N}=$ negative control for PCR, $\mathrm{P}=$ positive control for PCR. Numbers of samples are abbreviation of musem IDs (NMPC-GAS-00XX, XX = numbers used in this figure). Red number $=$ weak or not working sample. 
NMP insect collections we were able to obtain high-quality sequences from all but two samples. The failure and/or lower quality sequence of these two samples was clearly caused by problems after the DNA extraction, as indicated by obtaining high-quality sequences for these samples once re-amplified and re-sequenced.

Our study is naturally a pilot one, comparing mtDNA amplification success after a relatively short time after collecting the specimens and after only two exposures to cypermethrin. In addition, we used specimens killed by frost, which is not the case for usual specimens stored in dry collections (these are most frequently killed by ethyl acetate, chloroform, cyanide or ethanol in various concentrations). Based on our results, we hence cannot exclude some negative effect of cypermethrin on DNA quality of dry specimens with already partly degraded DNA.

However, some results of other studies based on dry specimens from NMP collection may provide some preliminary data for evaluating the effect of long-term repeated exposure to cypermethrin. For example, we obtained full barcode sequences ( $658 \mathrm{bp}$ ) in high bin quality from eight specimens of the genus Oegoconia Stainton, 1854 collected during seasons in 2000, 2004, 2008, 2010, and 2011. All samples were stored in NMP collection for at least three years, which means that they were fumigated at least six times (J. Šumpich 2018, unpubl. data). Another case was barcoding of dry flat-footed fly Agathomyia antennata (Zetterstedt, 1819) collected on 9.v.2012. During September 2016, a full barcode in high bin quality from this specimen was obtained (M. Tkoč 2018, unpubl. data). Sample was fumigated eight times. VondRÁčEK et al. (2018) used a dry NMP specimen of Protaetia (Potosia) cuprea brancoi (Baraud, 1992) collected on 19.vi.2009. The specimen was sequenced in the second half of 2011, which means it was fumigated at least four times before the DNA work was done. The quality of two fragments (cytochrome oxidase I and cytochrome b) was placed in high bin profile. Another case is a NMP specimen of flower chafer Oxythyrea dulcis Reitter, 1899 collected on 24.iv.2007 and sequenced in the second half of 2016, which means after at least 18 cycles of cypermethrin fumigation (D. Vondráček 2018, unpubl. data). In this case, two fragments (cytochrome oxidase I and internal transcribed spacer I) were placed in medium bin profile. The quality of these sequences could be lower due to the age of the sample. Based on this fragmentary data it seems that cypermethrin did not negatively affect the DNA quality (including nuclear markers) of these specimens, despite them being fumigated multiple times. We plan to continue with our experiment using the same sets of specimens as we used for this study to evaluate the effect of long-term repeated exposure to cypermethrin in more detail. In addition, we will start to test the effect of cypermethrin fumigation on the quality of selected nuclear markers. In contrast to the mitochondrial DNA which is present in each cell in multiple copies, nuclear DNA is only present in two copies in each diploid cell and hence may be more prone to degradation caused by chemicals including cypermethrin.
Only several chemicals used for anti-pest insecticide fumigation were tested in a similar way as cypermethrin in our study. Sulforyl fluoride $\left(\mathrm{SO}_{2} \mathrm{~F}_{2}\right)$ was tested using herbarium specimens with results analogous to ours (Whitten et al. 1999). Same results were obtained using naphtalene $\left(\mathrm{C}_{10} \mathrm{H}_{8}\right)$ and paradichlorobenzene $\left(\mathrm{C}_{6} \mathrm{H}_{4} \mathrm{Cl}_{2}\right)$ on insect samples (EsPELAND et al. 2010). On the other hand, studies testing dichlorvos (DDVP, 2,2-dichlorovinyl dimethyl phosphate, $\left.\mathrm{C}_{4} \mathrm{H}_{7} \mathrm{Cl}_{2} \mathrm{O}_{4} \mathrm{P}\right)$ or the mixture of methyl bromide with ethylene oxide $\left(\mathrm{CH}_{3} \mathrm{Br}+\mathrm{C}_{2} \mathrm{H}_{4} \mathrm{O}\right)$ showed that these substances highly affect the DNA in dry samples and they should not be used in museum collections (Espeland et al. 2010, Kigawa et al. 2003). Additional possibility, which was tested, is high temperature pest eradication system. ACKERY et al. (2004) tested this method in a similar way and they found out it did not affect the quality of DNA in their insect samples.

\section{Conclusions}

Based on our results, short-term exposure to cypermethrin from smoke shells used in fumigation process does not affect the quality of mtDNA (barcoding region) in dry insect samples and does not interfere with the subsequent laboratory steps of PCR, purification and Sanger sequencing. Additional tests are necessary to evaluate the effect of long-term repeated fumigation using this chemical, but indirect fragmentary data available to us indicate no or low negative effect on the mitochondrial as well as nuclear DNA quality even in that case.

\section{Acknowledgments}

We are grateful to our colleague Jan Cvrček (Department of Anthropology, National Museum, Prague) and his aunt Jaroslava Váňová and her family for the opportunity to collect fresh material of flower chafers in their garden. We are thankful to our colleague Zuzana Varadínová-Kotyková (Department of Zoology, National Museum, Prague) for the fresh material of brown-tailed cockroaches from her breeds. We are obliged to Jan Šumpich for his unpublished data on the genus Oegoconia, and Petr Dolejš with Radek Šanda for their useful comments on the experiment and the manuscript (all National Museum, Prague). This study was fully supported by the Ministry of Culture of the Czech Republic: project NAKI II (DG16P02B038).

\section{References}

ACKERY P. R., TESTA J. M., READY P. D., DOYLE A. M. \& PINNIGER D. B. 2004: Effects of high temperature pest eradication on DNA in entomological collections. Studies in Conservation 49(1): 35-40. doi: 10.1179/sic.2004.49.1.35

ANDERSEN J. C. \& MILLS N. J. 2012: DNA extraction from museum specimens of parasitic Hymenoptera. PLOS ONE 7(10)(e45549): 1-10. doi: 10.1371/journal.pone.0045549

BERZOLLA A., REGUZZI M. C. \& CHIAPPINI E. 2011: Preliminary observations on the use of low temperatures in the cultural heritage protection. Journal of Entomological and Acarological Research 43: 191-196.

BURNS J. M., JANZEN D. H., HAJIBABAEI M., HALLWACHS W. \& HEBERT P. D. N. 2008: DNA barcodes and cryptic species of skipper butterflies in the genus Perichares in Area de Conservación 
Guanacaste, Costa Rica. Proceedings of the National Academy of Sciences of the United States of America 105(17): 6350-6355. doi: 10.1073/pnas.0712181105

CANTALAMESSA F. 1993: Acute toxicity of two pyrethroids, permethrin and cypermethrin, in neonatal and adult rats. Archives of Toxicology 67(7): 510-513.

COLVIN M. 2014: Entomological Collections - Their Historic Importance and Relevance in the 21st Century. Available at: http://www. dispar.org/reference.php?id=92

ESPELAND M., IRESTEDT M., JOHANSON K. A., ÅKERLUND M., BERGH J. E. \& KÄLLERSJÖ M. 2010: Dichlorvos exposure impedes extraction and amplification of DNA from insects in museum collections. Zoology 7(2): 1-7. doi: 10.1186/1742-9994-7-2

GAMMON D. W., BROWN M. A. \& CASIDA J. E. 1981: Two classes of pyrethroid action in the cockroach. Pesticide Biochemistry and Physiology 15(2): 181-191. doi: 10.1016/0048-3575(81)90084-5

FLORIAN M. L. 1990: Freezing for museum pest eradication. Collection Forum 6: 1-7.

FOLMER O., BLACK M., HOEH W., LUTZ R. \& VRIJENHOEK R. 1994: DNA primers for amplification of mitochondrial cytochrome c oxidase subunit I from diverse metazoan invertebrates. Molecular Marine Biology and Biotechnology 3: 294-299.

GILBERT M. T. P., MOORE W., MELCHIOR L. \& WOROBEY M. 2007: DNA extraction from dry museum beetles without conferring external morphological damage. PLoS ONE 2(3)(e272): 1-4. doi: 10.1371/journal.pone.0000272

HEBERT P. D. N., PENTON E. H., BURNS J. M., JANZEN D. H. \& HALLWACHS W. 2004: Ten species in one: DNA barcoding reveals cryptic species in the neotropical skipper butterfly Astraptes fulgerator. Proceedings of the National Academy of Sciences of the United States of America 101(41): 14812-14817. doi: 10.1073/pnas.0406166101

JANZEN D. H. \& HALLWACHS W. 2016: DNA barcoding the Lepidoptera inventory of a large complex tropical conserved wildland, Area de Conservacion Guanacaste, northwestern Costa Rica. Genome 59: 641-660. doi: 10.1139/gen-2016-0005

KEARSE M., MOIR R., WILSON A., STONES-HAVAS S., CHEUNG M., STURROCK S., BUXTON S., COOPER A., MARKOWITZ S., DURAN C., THIERER T., ASHTON B., MENTJIES P. \& DRUMMOND A. 2012: Geneious Basic: an integrated and extendable desktop software platform for the organization and analysis of sequence data. Bioinformatics 28: 1647-1649. doi: 0.1093/bioinformatics/ bts 199

KIGAWA R., NOCHIDE H., KIMURA H. \& MIURA S. 2003: Effects of various fumigants, thermal methods and carbon dioxide treatment on DNA extraction and amplification: a case study on freeze-dried mushroom and freeze-dried muscle specimens. Collection Forum 18: 74-89.
KMENT P. \& RÉDEI D. 2018: A revision of the types of Heteroptera species described by Géza Horváth based on specimens from collections of Ladislav Duda and Emil Holub. Acta Entomologica Musei Nationalis Pragae 58: 275-295. doi: 10.2478/aemnp-2018-0025

LAWRENC J. L. \& CASIDA J. E. 1982: Pyrethroid toxicology: mouse intracerebral structure-toxicity relationships. Pesticide Biochemistry and Physiology 18(1): 9-14. doi: 10.1016/0048-3575(82)90082-7

MACHÁČKOVÁ L., MIKÁTOVÁ Š. \& HÁJEK J.: Catalogue of type specimens of beetles (Coleoptera) deposited in the National Museum, Prague, Czech Republic Staphylinidae: Euaesthetinae, Leptotyphlinae, Megalopsidiinae, Oxyporinae and Steninae. Acta Entomologica Musei Nationalis Pragae 57(2): 791-834.

NOTTON D. G. 2018: Identifying insect pests in museums and heritage buildings. $2^{\text {nd }}$ Edition. The Natural History Museum, London, 64 pp.

PASCUAL J. A. \& PERIS S. J. 1992: Effects of forest spraying with two application rates of cypermethrin on food supply and on breeding success of the blue tit (Parus caeruleus). Environmental Toxicology and Chemistry 11(9): 1271-1280. doi: 10.1002/etc.5620110907

PINNIGER D. B. \& HARMON J. D. 1999: Pest management, prevention and control. Pp. 152-176. In: CARTER D. \& WALKER A. (eds.): Care and Conservation of Natural History Collections. Butterwoth Heinemann, Oxford, 288 pp.

QUERNER P. 2015: Insect Pests and Integrated Pest Management in Museums, Libraries and Historic Buildings. Insects 6: 595-607. doi: 10.3390/insects6020595

SHAO W., KHIN S. \& KOPP W. C. 2012: Characterization of effect of repeated freeze and thaw cycles on stability of genomic DNA using pulsed field gel electrophoresis. Biopreservation and Biobanking 10(1): 4-11. doi: 10.1089/bio.2011.0016

SUAREZ A. V. \& TSUTSUI N. D. 2004: The value of museum collections for research and society. BioScience 54(1): 66-74. doi: 10.1641/0006-3568(2004)054[0066:TVOMCF]2.0.CO;2

VONDRÁČEK D., FUCHSOVÁ A., AHRENS D., KRÁL D. \& ŠÍPEK P. 2018: Phylogeography and DNA-based species delimitation provide insight into the taxonomy of the polymorphic rose chafer Protaetia (Potosia) cuprea species complex (Coleoptera: Scarabaeidae: Cetoniinae) in the Western Palearctic. PLoS ONE 13(2)(e0192349): 1-26. doi: 10.1371/journal.pone.0192349

WATTS P. C., THOMPSON D. J., ALLEN K. A. \& KEMP S. J. 2006 : How useful is DNA extracted from the legs of archived insects for microsatellite-based population genetic analyses? Journal of Insect Conservation 11: 195-198. doi: 10.1007/s10841-006-9024-y

WHITTEN W. M., WILLIAMS N. H. \& GLOVER K. V. 1999: Sulphuryl fluoride fumigation: effect on DNA extraction and amplification from herbarium specimens. Taxon 48(3): 507-510. 